\title{
CONSPIRING IN DREAMS: BETWEEN MISDEEDS AND SAVING ONE'S SOUL
}

\author{
Andrea Vanina Neyra \\ Consejo Nacional de Investigaciones Científicas y Técnicas \\ ARgentina
}

Date of receipt: $23^{\text {rd }}$ of April, 2015

Final date of acceptance: $9^{\text {th }}$ of November, 2015

\begin{abstract}
Thietmar of Merseburg was not an example of a virtuous, pious ecclesiastic; rather, he more closely exemplified an Amtsbischof and mentally anguished sinner. In the last book of his Chronicle, he narrates a dream in which he finds himself surrounded by a hostile crowd that incites him to consume a suspicious and peculiar drink: allegedly, it causes him to feel unpleasant sensations while performing his duties. Thietmar believes this apparition is the result of his sinful weakness. I will assess the role played by situations related to local conflicts in fomenting Thietmar's growing preoccupation with his salvation and the repercussions of his actions on his bishopric, pointing to Thietmar's concern about restoring the rights of the see and insuring that it was well-administered.
\end{abstract}

KEYWORDS

Thietmar, Chronicle, Bishop, Dream, Sinner.

Capitalia Verba

Thietmar, Chronicon, Episcopus, Somnium, Peccator. 


\section{Introduction}

Iste annus, quo hunc attitulavi librum, nativitatis meae quadragesimus est I. vel paulo amplius; in mense vero / Aprili et V. Kal. Mai. decimus ordinationis meae introivit annus. Et pridie in suburbio Gnezni archiepiscopi illius aecclesia cum mansionibus caeteris comburitur. Et quia humana res omnis semper in dubio est, libet evomere antidotum illud periculosum, quod miser dudum absorbui et nimis mihi hactenus id nocere persensi. In quadam curte mea Heslinge vocata nocte una cum requiescerem, per somnum vidi turbam astare magnam, tunc de apposita mihi testa aliquid manducare cogentem; et ego hos persentiens esse inimicos, primitus contempsi, ad ultimum vero in nomine Dei patris me istud percipere respondi. Quod cum eis multum displiceret et haec invisa congregatio id aliter fieri non posse videret, quasi gemens laudabat, quia me prorsus perdere conveniebat; et nisi tunc Dominicum nomen invocarem, sine perpetua salute manerem. Ex hac perceptione, ut mihi visum est, omnigenarum specie herbarum mixta, pessimarum varietates cogitationum sumpsi, quae, etsi me in divinis laudibus maxime turbent, tamen auxiliante Deo, quem hiis preposui, ad opus infaustum raro aut numquam me perduxerunt. Sufficit autem iniquae eorum voluntati, quod aliquam putant in me portionem habere. Sic enim alio tempore iterum me signatum eminus hii vallantes: ,Custodisti te', inquiunt, ,bene?' Et ego me ita sperare respondi; et subsequuntur: 'sed non sic erit in fine.' Illorum minas nec timeo nec blandiciis credo, quia haec cum auctoribus suis vanitas est; commissi quiantitatem mei admodum vereor. ${ }^{2}$

Cited above are the words Bishop Thietmar of Merseburg used to describe some of the torments he suffered in chapter 15 of his Chronicle, which I will return to after a brief profile of the author. Thietmar, who lived between 975 and 1018, was the

1. In fact, it is his $43^{\text {rd }}$ year. Thietmar von Merseburg. Chronik, ed. Werner Trillmich. Darmstadt: Wissenschaftliche Buchgesellschaft, 2011 : 457 (footnote 47). This edition follows Robert Hotlzmann's text. For quotations in Latin I am using the last bilingual Latin-German edition, published in 201 1, which contains an appendix to the introduction by Steffen Patzold.

2. "The year in which I dedicated this book was the forty-first since my birth, or a little more; 27 April marked the beginning of the tenth year since my ordination (1018). On the day before, in a suburb of Gniezno, the church of the archbishops burned down, together with other buildings. Indeed, because the affairs of humankind are always so doubtful, I shall now bring up that dangerous remedy which I, a wretch, previously ingested. I sense that it has subsequently done me much harm. One night, when I was resting at an estate of mine, called Heeslingen, I dreamed that I saw a large crowd of people standing near by. They were urging me to ingest something from a crock which had been placed next to me. I initially refused, realizing that they were hostile. Finally, I replied that I would take it, but only in the name of God the Father. They were most displeased with this. When they saw that otherwise it would not be done, however, this hateful gathering agreed, though with much grumbling. It had been decided that I would be completely destroyed. If I had not then invoked the name of the Lord, any chance of eternal salvation would have been lost to me. From this drink, which seemed to be a mixture of different types of herbs, I began to conceive various evil thoughts. They especially disturb me during celebrations of the liturgy, but with the help of God, which I always invoke, they have rarely or never led me to evil deeds. Nevertheless, it satisfied the evil will of these people, if they believed themselves to possess some part of me. On another occasion, they surrounded me again, although at a distance, and said: 'Are you guarding yourself well?' I responded that I hoped so. They continued, saying: 'But it will not be so at the end!' I neither fear their threats, nor believe their flattery, since both are as empty as their authors. It is only in respect to my own misdeeds that I feel any great concern". Thietmar von Merseburg. Chronik...: VIII, 15. For quotations in English I am using the existing English translation of the chronicle, based on the edition by Robert Holtzmann and on indications by Werner Trillmich (Thietmar of Merseburg, Ottonian Germany. The 'Chronicon' of Thietmar of Merseburg, ed. and trans. David Warner. Manchester-New York: Manchester University Press, 2001: 371-372). 
son of Sigfried, count of Walbeck, whose domain is in the present-day German state of Saxony-Anhalt. ${ }^{3}$ Educated in the prestigious cathedral chapter at Magdeburg, ${ }^{4}$

3. Thietmar's parents were Sigfried, Count of Walbeck, and Cunegunda, daughter of Count Henry I of Stade. They had six children: Henry, Frederick, Thietmar, Sigfried, Bruno and Oda. Three of them followed an ecclesiastical career: Thietmar was Bishop of Merseburg (1009-1018), Sigfried was a monk and abbot at Berge and bishop of Münster (1009-1022), and Bruno was a monk at Corvey, abbot at Berge and Nienburg and Bishop of Verden (1034-1049). For more detail, see: Thietmar of Merseburg, Ottonian Germany...: 49-52. The translator suggests literature on Thietmar's family history: Warner, David. "Introduction: Thietmar, Bishop and Chronicler", Thietmar of Merseburg, Ottonian Germany. The Chronicon of Thietmar of Merseburg, ed. and trans. David Warner. Manchester-New York: Manchester University Press, 2001: 49 (footnote 299).

4. Previously, while still a child, Thietmar was educated at the Quedlinburg Abbey and in the Berge Monastery - the latter also attended by his brothers, as I have just pointed out. Thietmar von Merseburg. Chronik...: IV, 16; Warner (Warner, David. "Thietmar of Merseburg: the Image of the Ottonian Bishop", The Year 1000, Religious and social reponse to the turing of the first Millennium, Michael Frasetto, ed. Houndsmills: Palgrave, 2002: 97) defines Thietmar as a product of the Magdeburg cathedral school, which occupies a marginal place in Stephen Jaeger's vast study about such educational centres: Jaeger, Stephen. The Envy of Angels. Cathedral Schools in Medieval Europe, 950-1200. Philadelphia: University of Pennsylvania Press, 1994. There, the author mentions the example of Magdeburg among other cathedral schools which became a place of training and preparation for service at court (secular and episcopal) in the context of their flourishing in the mid-tenth century. In fact, "A cathedral school education becomes virtually a requirement for higher office in the imperial church". Jaeger, Stephen. The Envy of Angels...: 47. On the other hand, Jaeger (Jaeger, Stephen, The Origins of Courtliness - Civilizing Trends and the Formation of Courtly Ideals - 939-1210. Philadelphia: University of Pennsylvania Press, 1991), studies the relationship between bishops and courtliness within a system of education traced to Brun of Cologne, stating the "...direct connection between the royal court and the rise of these cathedral schools... The educational goal of the cathedral schools was no longer the training of clerics in pastoral duties but rather the training of talented young men, noblemen close to the king above all, for state administration. Here a humanistic education became an essential part of preparation for service to the empire; the curriculum was adapted to the requirements, both human and practical, of an office". Jaeger, Stephen. The Origins of Courtliness...: 4-5. The fact that in the Early Middle Ages royal courts were not fixed in a particular residence, but rather moved with the German King needs to be taken into consideration: The King and his changing, at times volatile, retinue of dukes, counts, bishops and archbishops were hosted by bishops and secular nobles when they did not stay in one of the royal palaces (Pfalzen), see: Jaeger, Stephen. The Origins of Courtliness...: 4-5. The role of the imperial chapel (Hofkapelle) in providing human resources for the office of bishop was studied by Josef Fleckenstein in his two volume classic work: Fleckenstein, Josef. Die Hofkapelle der deutschen Könige. I. Teil, Grundlegung. Die karolingische Hofkapelle. Stuttgart: Anton Hiersemann, 1959; Fleckenstein, Josef. Die Hofkapelle der deutschen Könige. II. Teil, Die Hofkapelle im Rahmen der ottonisch-salischen Reichskirche. Stuttgart: Anton Hiersemann, 1966; Stephen Jaeger summarises this tendency: "The natural tendency of court officers to emancipate themselves from direct service at court and to step into high positions in the kingdom had its counterpart in the chapel in the progression from chaplain to bishop. Service to the king in his court had been an avenue to a bishopric since late antiquity and this continued in Carolingian times. But the frequency of this route as well as its political importance increased dramatically under Otto the Great and his successors". Jaeger, Stephen. The Origins of Courtliness...: 21. Fleckenstein deals with the quantitative and qualitative changes in the Hofkapelle in his second volume, specifically: Fleckenstein, Josef. Die Hofkapelle...: 50-63. There he states that Daß heißt, daß die Erweiterung der Hofkapelle im wesentlichen auf eine Stärkung des adligen Elementes, der Weltgeistlichkeit und der Kanoniker in ihr hinauslief. Mit ihrer Erweiterung ging sozusagen eine qualitative Steigerung Hand in Hand. Dem entspricht das Bild der Bischofspromotionen aus den Reihen der Kapelläne ("That means that the enlargement of the Hofkapelle essentially meant the strengthening of the noble element, the secular clergy and the canons. Along with its extension there was a simultaneous elevation of its quality. This is consistent with the image of the promotion of bishops who were chosen from among the chaplains"). Fleckenstein, Josef. Die Hofkapelle...: 52. In the same volume, the author studies the changes in and 
he served as provost of Walbeck Abbey in 1002; two years later he became a priest and on April 24 $4^{\text {th }}, 1009$ was named bishop of Merseburg, a suffragan diocese of Magdeburg - an Ottonian institution established to minister to the empire's eastern territories. ${ }^{5}$ Between 1012 and the year he died (1018) Thietmar wrote his famous Chronicle dedicated to the Saxon kings and his own bishopric. In it he narrates not only Ottonian deeds and significant events during their reigns, ${ }^{6}$ the bishop of Merseburg also notes autobiographic details, ${ }^{7}$ reflects on the appropriate role for himself and his colleagues, and recounts certain situations arising from disputes over power and possessions within the diocese. He includes comments on other prominent ecclesiastics and laymen as well.

relationship of the chapel with the imperial church: Fleckenstein, Josef. Die Hofkapelle...: 119-134. In additon, Finck von Finckenstein (Finck von Finckenstein, Albrecht Graf. Bischof und Reich. Untersuchungen zum Integrationsproze $\beta$ des ottonisch-frühsalischen Reiches (919-1056). Sigmaringen: Jan Thorbecke Verlag, 1989) explored the origin, career path and role of selected bishops and bishoprics in the functioning of the imperial system in the context of his study of the process of integration of the Reich in the tenth and eleventh centuries.

5. Magdeburg was created as a border-see from where efforts to Christianise the Slavs were launched. The following constitutes the basic literature on the bishopric: Beumann, Helmut. Theutonum nova metropolis. Studien zur Geschichte des Erzbistums Magdeburg in ottonischer Zeit. Köln-Weimar-Vienna: Böhlau Verlag, 2000; Puhle, Matthias, ed. Otto der Grosse, Magdeburg und Europa, Band I - Essays. Mainz: Verlag Philipp von Zabern, 2001; Muelverstedt, George Adalbert von, ed. Regesta archiepiscopatus Magdeburgensis. Sammlung von Auszügen aus Urkunden und Annalisten zur Geschichte des Erzstifts und Herzogthums Magdeburg. Erster Theil. Bis zum Tode des Erzbischofs Wichmann (1192). Magdeburg: Baensch, 1876; Israël, Friedrich, ed. Urkundenbuch des Erzstifts Magdeburg. Teil 1 (937-1192). Magdeburg: Selbstverlag der Landesgeschichtlichen Forschungsstelle für die Provinz Sachsen und für Anhalt, 1937; Claude, Dietrich. Geschichte des Erzbistums Magdeburg bis in das 12.Jahrhundert. Teil I. Die Geschichte der Erzbischöfe bis auf Ruotger (1124). Köln-Vienna: Böhlau, 1972; Kehr, Paul. Das Erzbistum Magdeburg und die erste Organisation der christlichen Kirche in Polen. Berlin: Verlag der Akademie der Wissenschaften, 1920.

6. I dealt with the topic in an article where, focusing on the prologues of the books in Thietmar's Chronicon, the aim was to show how the author perceived the deeds of the Ottonian kings from the perspective of the interests of his own see: Neyra, Andrea Vanina. "Glorias y aflicciones del imperio otoniano: la Crónica de Thietmar de Merseburg". Revista electrónica anual: Actas y Comunicaciones del Instituto de Historia Antigua y Medieval, 9 (2013): 1-12.

7. On Thietmar of Merseburg, see the following basic literature: Goez, Werner. "Thietmar von Merseburg, Geschichtsschreiber $(975+1018) "$, Gestalten des Hochmittelalters. Personengeschichtliche Essays im allgemeinhistorischen Kontext. Darmstadt: Wissenschaftliche Buchgesellschaft, 1983: 70-83; Lippelt, Helmut. Thietmar von Merseburg. Reichsbischof und Chronist. Köln-Vienna: Böhlau Verlag, 1973; Seidel, J. Jürgen. "Thietmar Bischof von Merseburg (975-1018)". Biographisch-Bibliographisches Kirchenlexikon, Herzberg: Traugott Bautz, 1996: XI, 1212-1213; Seidel, J. Jürgen. "Thietmar Bischof von Merseburg (975-1018)". Biographisch-Bibliographisches Kirchenlexikon. 13 October 2010, Verlag Traugott Bautz GmbH. 17 April 2015 <http://www.bbkl.de/lexikon/bbkl-artikel.php?art=./T/Th/thietmar_b_v_m.art>; Die Chronik des Bischofs Thietmar von Merseburg und ihre Korveier Überarbeitung, ed. Robert Holtzmann. Berlin: Weidmannsche Buchhandlung, 1935: VII-XXVIII; Warner, David. "Thietmar of Merseburg...": 85-110; Warner, David. "Introduction: Thietmar, Bishop and Chronicler...": 1-64; Trillmich, Werner. "Einleitung", Thietmar von Merseburg. Chronik, ed. Werner Trillmich. Darmstadt: Wissenschaftliche Buchgesellschaft, 2011: IX-XXX; Patzold, Steffen. "Nachtrag". Thietmar von Merseburg. Chronik, ed. Werner Trillmich. Darmstadt: Wissenschaftliche Buchgesellschaft, 2011: XXXII-XLVIII; Leyser, Karl. J. "Three Historians", Communications and Power in Medieval Europe. The Carolingian and Ottonian Centuries, Timothy Reuter, ed. London-Rio Grande: The Hambledon Press, 1994: 19-28. While most of Leyser's pages are devoted to Nithard and Widukind of Corvey, the last two do contain some basic information about Thietmar, as well as a short description of his literary style. 


\section{Thietmar the sinner: somewhere between a topos and exaggeration}

The point of departure for this paper was my desire to reflect on the autobiographical data and on the identity of the author of the Chronicle within the broader framework of a study of bishops and missionaries in general whose activity was devoted to Christianising Central and Eastern Europe. From this perspective the question now becomes what makes the autobiographical details Thietmar of Merseburg inserts in his Chronicle noteworthy and why does he do it in the first place. The bishop's autobiographical references as a whole, which have been exhaustively examined in a recent article which I will refer to below, ${ }^{8}$ are not my concern here. I will focus exclusively on analysing the textual and historical context of the dream ${ }^{9}$ cited above and sketching out a possible interpretation.

8. Goetz, Hans-Werner. "Die Chronik Thietmars von Merseburg als Ego-Dokument: ein Bischof mit gespaltenem Selbstverständnis", Ego trouble. Authors and Their Identities in the Early Middle Ages, Richard Corradini, Matthew Gillis, Rosamond McKitterick, Irene van Renswoude, eds. Vienna: Verlag der Österreichischen Akademie der Wissenschaften, 2010: 259-270. The article proposes to take into consideration the perspective of the 'Ego-Trouble' studies to analise Thietmar on four levels: 1) as a chronicler, 2) in his family context, 3) as an undeserving/unworthy bishop, and 4) as a neurotic and dissatisfied individual.

9. Although I do not explore the complex question of the importance of dreams in Christianity here, it does play a role in the underlying basis for the subject matter covered. According to Jacques Le Goff, one of the consequences of the formation of Christian oneirology was their democratisation: ... le christianisme crée en profondeur une situation favorable à l'extension du domaine significatif $d u$ rêve...étend la possibilité de l'onirocritique à tous les rêves. Tous les rêves sont significatifs. Cette généralisation correspond à la fois à la 'démocratisation' du rêve dont $j$ ' ai déjà parlé et à la croyance du christianisme en l'omniprésence de la volonté divine...: dans toutes les manifestations humaines et, notamment, celles qui semblent plus particulièrement en contact avec le surnaturel ("The Christianity created a deep situation favourable to an important expansion of the dream (...) and expanded the possibility of an oneiric analysis of every dream. All the dreams have a signification. This generalisation corresponds to a democratization of the dreams, according I have stated, and a Christian belief in the omnipresence of the divine will (...) in every form of human expression and, especially, those wich appear to be in closer contact with the supernatural essence"). Le Goff, Jacques. "L'imaginaire médiéval", Un autre Moyen Âge. Paris: Quarto Gallimard, 1999: 713-714. On the other hand, medieval beliefs regarding dreams and how to interpret them were influenced by classical culture: Las creeencias más comunes respecto al sueño aparecen ya establecidas en época clásica: entre los griegos y los romanos estaba difundida la idea de que lo visto en sueños era cierto y, por tanto, servía como medio de conocimiento de una realidad más allá del mundo o de contacto con los seres sobrenaturales. Para explicar este fenómeno acudían a que o bien el alma recibía el mensaje de la divinidad como destinataria pasiva, o bien el alma, libre de la atadura del cuerpo, se desplazaba y conocía una realidad superior. La información que se había obtenido durante el sueño debía tenerse presente no sólo en el ámbito individual sino que se proyectaba sobre el grupo, especialmente si el receptor desempeñaba un papel relevante dentro de su comunidad ("The most common beliefs related to the dreams were established during the Classic epoch: among the Greeks and Romans, the idea that everything seen in dreams was true was extended and, consequently, it was a knowledge's way for a reality beyond the world or a contact system with supernatural beings. This was explained both, by considering that the soul was a passive receptor of the divine message and by considering that it, free form any attachment to the body, moved and go to know a superior reality. The information received during sleep should be kept present for the dreamer and shared with the social group, especially when the receptor had an important role into the community"). García-Monge, Isabel. "El sueño en la Edad Media cristiana: categorías y tópicos esenciales", Medioevo utópico. Sueños, ideales y utopias en el imaginario medieval, Martín Alvira, Jorge Díaz Ibáñez, coords. Madrid: Sílex, 2011: 17. In his study endeavoring to delineate the cultural view of dreaming in the Middle Ages, Steven Kruger underlines the need for caution when interpreting source material: "Dream theory and practical responses to dreams are not necessarily commensurate. Literary 
It should be noted from the outset, however, that certain topoi stressing humility and indignity in words and images the chronicler employs to refer to himself are clearly exaggerated. By way of example,

\begin{abstract}
Quam egreios proceres in hac urbe vidi, quorum laudabilem vitam pro debito nec sum imitatus neque memoriam eorum post solutionem carnis assequutus! Heu me misero, qui tot tantisque immerito sum coniunctus in fraternitate, sed longe dissimilis existo in condigna conversacione! Ego in peccatis iam pene mortuus, ut spero, vivam in lucido conspectu Dei eorundem meritis refocilatus; quia, etsi in hoc seculo parum boni operatus sum, tamen defunctorum semper memor sum. Voluntas mea interdum bona est; sed quia eidem vires aptas suggerere non studeo, parum prodest. Semper me accuso, sed sicut debui reatum non solvo; sumque ideo in omnibus corrigibilis, quia me non converto ad eum, qui est super omnia laudabilis. Agnosce, lector, procerem, et videbis in me parvum homuntionem, maxilla deformem leva et latere eodem, quia hinc olim erupit semper turgescens fistula. Nasus in puericia fractus ridiculum de me facit. Idque totum nil questus essem, si interius aliquid splenderescerem. Nunc sum miser, nimis iracundus et ad meliora inflexibilis, invidus, subsannans alios ipse deridendus, nulli pro debito parcens, glutto et simulator, avarus ac detractor et, ut haec convicia merito illata concludam, peior seum, quam possit dici vel ullatenus estimari. Unicuique sit fas non solum muttire, quin pocius in aperto, quia peccator sum, dicere, et post correptionem fraternam congruit suppliciter orare. Multi a populo laudantur, nisi pauca res eis obstaret, quod inter optimos haberentur; et quia verum est, hominibus de perfectione iusta nimis deesse, quid prodest de inferioribus hiis tale quid promulgare? Omnis laus in fine canitur, et mortalis conversacio igne probatur. ${ }^{10}$
\end{abstract}

depictions of dreams, even when directly invoking theoretical material, also depend upon literary traditions and "real-life" experience. Historical and (auto)biographical accounts may be distorted in a variety of ways, their form shaped by literary topoi, their content determined by political, didactic, and religious motives". Kruger, Steven F. Dreaming in the Middle Ages. Cambridge (UK): Cambridge Universtity Press, 1992.

10. "How excellent are the men I have seen in this city and yet, I have not imitated their praiseworthy lives as I ought to have, nor have I cultivated their memory following the dissolution of their flesh. Woe is me, a wretch joined in fraternity with so many, but with an existence so dissimilar to their worthy manner of life. Though almost dead in my sins, I hope to live again in the clear vision of God, revived by their merits. Even if I have done too little good in this world, I have always been mindful of the dead. Moreover, my intentions are good. But they have produced little because I have not troubled myself to devote sufficient force to them. I always accuse myself, but have not freed myself of guilt as I ought to have. Therefore, I require correction in all things because I have not directed myself to him who is praiseworthy above all. Acknowledge, O reader, the great Lord. In me, however, you will see a tiny little man whose jaw and left side of the face are deformed by an ulcer which erupted there and continues to swell. The nose, broken in childhood, gives me a laughable appearance. Of all of that I would regret nothing, if only my inner character were bright. Now, I am a wretch, too prone to anger and resistant to virtue, envious, derisive towards others though myself worthy of derision, granting forgiveness to none though obligated to do so. I am a glutton and a hypocrite, greedy and disparaging. And, to conclude, these well-deserved reproaches, I can say that I am much worse than one can possibly say or estimate in any way. It would be permissible for anyone not only to mutter but to openly announce that I am a sinner, and it would be appropiate for me to humbly ask for fraternal correction. Many are praised by the people and very little prevents them from being included among the best. But because it is true that complete perfection is impossible for mortal men, what use is there in speaking of those who are even more inferior? The praise of each will be sung at the end and the lives of mortals will be tested in the fire". Thietmar von Merseburg. Chronik...: IV, 75. 
Furthermore, Thietmar incriminates himself for having committed grave sins such as simony ${ }^{11}$ and nonfulfillment of penance ${ }^{12}$ and, above all, for having profaned of the tomb of Willigis, a predecessor in the post of provost of the Walbeck family church. According to the bishop of Merseburg, this last sacrilegious deed, the likely cause of an illness and the recurring anxiety that followed him from that moment on, appears to have manifested itself in a dream in which the chronicler hears the former provost lamenting: 'Hic ego sum', inquid, 'Willigisus, qui culpa tui errans vagor'.13

This exaggerated characterisation of the fate of the sinner recently led HansWerner Goetz to label Thietmar as neurotic in an article in which the dream I analyse here is cited to support the premise that the Chronicle is an Ego-Dokument. ${ }^{14}$ This could be interpreted as both an example of the exaggerated self-criticism already mentioned as appropriate for a Christian concerned about saving his soul. Indeed, regarding the chronicler's dreams Goetz states: Die vielen Traumgeschichte dürfen in Thietmars Deutung gewiss als Folge eines schlechten Gewissens gedeutet werden. ${ }^{15}$

Referring back to chapter fifteen of the eighth book with which this article began, we find a dream, a drink, ${ }^{16}$ the hostility of the crowd, and the adverse effects

11. Thietmar von Merseburg. Chronik...: VI, 43-44.

12. Thietmar von Merseburg. Chronik...: VI, 46.

13. "I am here', 'Willigis, forced by your sin to wander without rest'". Thietmar von Merseburg. Chronik...: VI, 45.

14. Goetz, Hans-Werner. "Die Chronik Thietmars...": 259-270. The editors of the volume which includes this Goetz's contribution state from the very beginning the methodological perspective that guides the authors' studies: "We were not so much concerned with the definition of the individual in the Early Middle Ages, nor whether an author betrays genuine emotion, hints of private life, feelings or convictions. Rather, we have historicized the concept of the individual and sought, through an analysis of what they wrote, to uncover all the elements that contribute to the make-up of an individual... The notion of 'ego-trouble', furthermore, is used in this volume as a methodological tool to analyse the texts written by individuals in the past, whether ostensibly designed to tell us about the author, or constructed for a purpose other than revealing anything about the author him- or herself... Constructing an individual identity often led people to go down unexpected paths to achieve their own special balance between selfassertion, self-fashioning and the social and intellectual discipline within which they wrote". Corradini, Richard. "Foreword", Ego trouble. Authors and Their Identities in the Early Middle Ages, Richard Corradini, Matthew Gillis, Rosamond McKitterick, Irene van Renswoude, eds. Vienna: Verlag der Österreichischen Akademie der Wissenschaften, 2010: 8.

15. "The many dream stories in Thietmar's interpretation should certainly be interpreted as a consequence of a bad conscience". Goetz, Hans-Werner. "Die Chronik Thietmars...": 267-268.

16. On magical potions and superstitions, see the following basic (and classic) literature: Cardini, Franco. Magia, brujería y superstición en el Occidente Medieval. Barcelona: Península, 1999; Daxelmüller, Christoph. Historia social de la magia. Barcelona: Herder, 1997; Flint, Valerie I. J. The Rise of Magic in Early Medieval Europe. Princeton: Princeton University Press, 1991; Giordano, Oronzo. Religiosidad popular en la Alta Edad Media. Madrid: Gredos, 1983; Gurevich, Aaron. Medieval popular culture, problems of belief and perception. París-Cambridge (UK): Éditions de la Maison des Sciences de l'Homme-Cambridge University Press, 1990; Harmening, Dieter. Superstitio. Überlieferungs- und theoriegeschichtliche Untersuchungen zur kirchlichtheologischen Aberglaubensliteratur des Mittelalters. Berlin: Erich Schmidt Verlag, 1979. Kieckhefer, Richard. La magia en la Edad Media. Barcelona: Crítica, 1992; Schmitt, Jean-Claude. Historia de la superstición. Barcelona: Crítica, 1992; Thomas, Keith. Religion and the decline of magic. New York: Oxford University Press, 1997; Vogel, Cyrille. "Pratiques superstitieuses au début du XIe siècle d'après le Corrector sive medicus de Burchard, évêque de Worms (965-1025)", Mélanges offerts à Edmond-René Labande. Poitiers: Centre d'Études supérieures de civilisation médiévale, (IXe - XIIe siècles), 1974: 751-761. 
(evil thoughts and irritation during liturgical celebrations) on the chronicler that followed. In the next chapter (sixteenth of the eighth book), the bishop attributes these phenomena to sinful weakness:

\begin{abstract}
Et veraciter id scio, quod talis fantasia, quamvis corporaliter appareat, Per se hominibus non noceat. Sed cum peccando faciem divinam a nobis avertimus, Illorum vesanas manus nemini parcentes miseri incidimus; et ab hiis protinus absolvimur, cum aut ipsi convertimur vel ab electis Dei visitatione crebra fovemur. Si quis vero compos sui meditatur in lege Dei, non hic a talibus appetitur, sed pocius timetur, non a se, sed ex eius, quem is diligit, sancta potestate; quia custos est Deus omnium semet ex toto corde semper amancium. Ego peccator et fragilitati meae per omnia conscius, quia summis consolationibus non innitor, quid mirum, si ab infimis quacior? Et haec idcirco dixi, ut tu, lector, mortalitate ac innata humanitate mihi consimilis in hoc consensu me graviter peccasse scias et amminiculis indeficientibus succurras. Heu mihi misero, qui in hoc seculo multos spiritualiter adiuvare debui / nec hiis prosum nec me tueri possum! Unde autem predicta temptatio mihi evenerit, fidelibus tuis auribus infundo. Multis hominibus a predictorum vexacione hostium laborantibus subvenire studui et propter hoc ad insidiandum mihi eosdem accendi vehementer, quiamvis in malum proni sint semper. Spero autem in Deum omnipotentem, ut non ad consumendum me hiis tradat, sed post purgationem diram clementer eripiat. ${ }^{17}$
\end{abstract}

Apparitions pursue sinners. Thietmar is profoundly aware of his faults. Does this then constitute just one more element for characterising him as a 'neurotic' personality?

\title{
3. Textual and historical context of the dream
}

The chronicler's humility and exaggerated self-blame have been correctly interpreted as the result of the Christian fear of endangering the salvation of the soul. However, in the specific case of the dream recounted at the beginning of this article,

17. "In truth, I know that such apparitions may not harm us on their own account, however corporeal they may appear. But when our sinning causes God to avert his face from us, we wretched mortals fall into their frenzied and merciless hands. We are immediately freed from them, however, if we mend our ways or if we benefit from the constant intercession of God's chosen ones. Anyone who exhibits selfcontrol and thinks on God's law will not be sought out by them, but rather feared. Indeed, this fear is not inspired by such mortals themselves, but rather by the holy power of the one they love. God is the protector of all who love him with constancy and with all their heart. If I, a sinner well aware of my weakness in all things, do not build on such a secure foundation, is it any surprise that I am shaken by those vile beings? Dear reader, similar to me in your mortality and innate humanity, I have said these things that you may know how grievously I sinned by agreeing to their demand, and support me with unfailing aid. Woe is me, this miserable wretch who ought to render spiritual aid to so many of his fellow mortals, but can protect neither them nor himself! I shall now entrust to your faithful ears the source of the aforesaid temptation. I have tried to support many persons suffering from the persecution of the enemies mentioned above. By doing so, I have incited them to attack me even more, though, to be sure, they are always prone to evil. I hope that omnipotent God will not permit me to be consumed by them, but rather, following a dreadful purgation, mercifully rescue me". Thietmar von Merseburg. Chronik...: VIII, 16. 
this preoccupation is not an abstract one. I will now analyse the textual framework in which the dream is placed in order to demonstrate the degree to which certain concrete situations arising out of local conflicts pertaining to the dream's historical context might have acted as factors increasing Thietmar's concern about both the salvation of his soul and the repercussions of his actions on his diocese.

In the two chapters following the author's recounting of the dream and reflecting on the apparitions, ${ }^{18}$ readers' attention is diverted to certain matters affecting the empire. In the nineteenth chapter of the eighth book, however, the narrative returns to the subject of the bishop's dream and the diocese of Merseburg when the chronicler narrates the attack carried out on his properties by the 'bastard Adalbert', about whom no further details are given:

Eadem tempestate aeclesia mihi indigno commissa multum mea id exigente culpa sustinuit dampnum. Namque misericors et paciens Deus noluit amplius inultum relinqui, quod crebra sui castigacione nequivit prohiberi, percuciens eam in mansuetudine et non in furoris sui digna retributione; ministros utiles sibi haec perdidit et facinus meum cotidie ingemiscit. In predicto etenim mense dedecus magnum eidem ac mihi inlatum est ab ibrida Aethelberto, qui curtem meam invadere eamque frangere servili collectione presumpsit. ${ }^{19}$

Thietmar then sets out to explain what provoked the attack, ${ }^{20}$ which was purported to be a retroactive consequence of the dissolution of the diocese of Merseburg from

18. Thietmar von Merseburg. Chronik...: VIII, 17-18.

19. “At the same time, the church, committed to me in spite of my unworthiness sustained much damage because of my guilt. For our patient and merciful God was no longer willing to leave unavenged that which his constant warnings had failed to prevent. He had previously treated our church with mildness and withheld his deservedly angry punishment. Now our church lost many useful servants and daily had cause to lament my misdeed. In the month of June, a great outrage was inflicted upon it -and me- by the bastard Adalbert, who dared to attack and destroy one of my estates with a servile mob". Thietmar von Merseburg. Chronik...: VIII, 19.

20. Quod vero hos ad haec agenda inflammaverit, veraciter explicabo. Secundi Ottonis larga benignitas cunctis pleniter arridens quendam forestum inter Salam et Mildam fluvios et Siusili ac Plisni pagos iacentem nostrae concessit aecclesaie, temporibus Gisileri antistitis et Gunterii marchionis. Post lugubrem vero nostrae sedis destruccionem, regnante tunc tertio Ottone, Ekkihardus marchio forestum ad locum Sumeringi dictum acquisivit et cum eodem nostrum commutavit. Renovator autem nostrae tunc dignitatis rex Heinricus cum maxima parte appertinentium, presentibus cunctis optimatibus suis et confratribus hiis Herimanno et Ekkihardo id defendere non valentibus, iudiciaria lege hunc restituit. Cumque hic in nostrae dominio aecclesiae plus quam duodecim annos staret et hunc Hirimannus comes LX mansis redimere ex mea potestate nullatenus valuisset, visum est ei, ut eum sibi et confratri super duorum proprietatem burgwardorum, Rochelinti ac Titibutziem, imperatoriis vendicaret preceptis, sperans antiquiorem nostram confirmacionem diu esse abolitam. Quod cum mihi is aperiret, id nil proficere sensit. Namque in Magadaburg et in presentia imperatoris nostri precepta utris/que ostenduntur et munera nostrimet in omnibus priora esse convincuntur. Tandem predictus comes presente suimet fratre ac id audiente haec fatur: 'Quidquid hactenus in hiis fecimus, non ob temeritatem aliquam, sed quam habuisse speravimus iusticiam. Nunc autem id omittamus' ("Now, I shall truthfully explain what provoked them to do this. In the times of Bishop Giselher and Margrave Gunther, the generous beneficence of Otto II, smiling broadly upon everyone, granted to our church a certain forest. It was situated between the rivers Saale and Mulde, and between the districts of Siusuli and Plisne. After the sad destruction of our diocese, during the reign of Otto III, Margrave Ekkehard [I] acquired another forest, in a place called Sömmering, and traded it for the one belonging to us. Afterwards, along with most of our property, this forest was returned to us by King Henry, the restorer of our office. This restitution was confirmed through a legal judgement, in the presence of all the king's 
981-1004. ${ }^{21}$ During the era of the fervently criticized bishop Giselher (971-981 ${ }^{22}$ -before being dissolved and Giselher named archbishop of Magdeburg (9811004), the bishopric had been granted a forest by emperor Otto II, which was later exchanged for another belonging to the margrave Ekkehard I. ${ }^{23}$ When the diocese was restored to Wigbert in 1004 during the reign of Henry $\mathrm{II}^{24}{ }^{24}$ the forest formed part of the properties recovered, despite the efforts of its former owners (Ekkehard I and his inheritors, Herman and Ekkehard II) to retain it. ${ }^{25}$ The conflict remained unresolved, with Ekkehard II constructing enclosures that were objected to by Thietmar who, on a visit to that area of his diocese, felt obliged to act: he cut the

leading men, and with the brothers Herman and Ekkehard II unable to support their claim. This forest had been in our church's possession for more than twelve years. And Margrave Herman had in no way succeeded in reacquiring it by offering me sixty manses of land. Nevertheless, he thought that he and his brother might still claim it by means of imperial diplomata relating to the possession of two burgwards, Rochlitz and Teitzig. He hoped that the old document which confirmed our rights had long been lost. When he showed me his documents, he realized that they would do him no good. For at Magdeburg, when our respective diplomata were presented before the emperor, it was clear that our church's claims took precedence, in every way. At last, in his brother's presence and hearing, the aforesaid margrave declared: 'Until now, whatever we have done regarding this matter has been undertaken because we hoped to have justice, and not out of recklessness. Now let us give it all up'"). Thietmar von Merseburg. Chronik...: VIII, 20. As noted by David Warner, “...the two men had not renounced their claim, but rather signalled their intent to pursue it by feud". Thietmar von Merseburg. Chronik...: VIII, 20 (footnote 42). Regarding the ties between Otto III and Ekkehard and the general practice of bestowing offices and granting lands as benefices and gifts by the rulers, Timothy Reuter draws attention to our source: "Thietmar cites as a mark of special favour in which Ekkehard of Meißen was held by Otto III the fact that the emperor converted most of Ekkehard's benefices into propietas". Reuter, Timothy. Germany in the Early Middle Ages 800-1056. London-New York: Longman, 1998: 198.

21. Thietmar von Merseburg. Chronik...: III, 14.

22. Thietmar von Merseburg. Chronik...: II, 36-37. Furthermore, in the third book of his Chronicle, Thietmar characterises Giselher as a mercenary: eiusdem non pastor sed mercenarius ("not its pastor but rather a mercenary"). Thietmar von Merseburg. Chronik...: III, 14.

23. The exchange was made between Ekkehard and Giselher of Magdeburg. Regarding the forest, the trade was possible thanks to the intervention of Erzbischof Giselher in the year 997: Monumenta Germaniae Historica. Die Urkunden der deutschen Könige und Kaiser (Diplomata regum et imperatorum Germaniae) 2. Band 2. Teil, Die Urkunden Otto des III, ed. Theodor von Sickel. Hannover: Hannsche Buchhandlung, 1893: 668669.

24. Monumenta Germaniae Historica. Die Urkunden der deutschen Könige und Kaiser (Diplomata regum et imperatorum Germaniae). Die Urkunden der deutschen Könige und Kaiser, 3. Band 2. Die Urkunden Otto Heinrichs II. und Arduins, ed. Theodor von Sickel. Hannover: Hannsche Buchhandlung, 1900-1903: 78-82.

25. The brothers Hermann and Ekkehard II tried to regain it by presenting documentation related to their possessions and, after the prerogative to Merseburg was finally proved, they tried to recover it by means of a dispute: Thietmar von Merseburg. Chronik...: VIII, 20. On the Ekkehardiner family and their bonds with the Ottonian dynasty, see: Reuter, Timothy. Germany...: 192-195. They were in charge of the Meißen march between 895 and 1046. Reuter, Timothy. Germany...: 194. In addition, Gabriele Rupp (Rupp, Gabriele. Die Ekkehardiner, Markgrafen von Meißen, und ihre Beziehungen zum Reich und zu den Piasten. Frankfurt am Main: Peter Lang, 1996), studied the rise of the Ekkehardiner family, which became a relevant factor in the networks of political power in Central Europe, and their relationships with the Piast dynasty from Poland. On the marches around the bishoprics of Merseburg and Meißen -important defensive and interactive frontiers facing the Slavic east - as well as the relationships between their authorities and the secular and ecclesiastical powers, see: Eldevik, John. Episcopal Power and Ecclesiastical Reform in the German Empire. Tithes, Lordship, and Community, 950-1150. Cambridge (UK): Cambridge University Press, 2012: 230-242. 
cords of the enclosures and forbid the alleged usurper the right to use the forest and withhold tithes corresponding to the church of Merseburg. ${ }^{26}$ Ekkehard responded by sending his milites to harass Thietmar, who was defended by his guards, and by extending hostilities to include not only the latter's people, but also personages such as archbishop Gero and count Sigfried as well. ${ }^{27}$ It is worth noting that the difficulties suffered by the author's colleagues — which should be understood as examples of the ill-treatment afflicting bishops 'in different parts of the world', are once again preceded by self-criticism: Ego in flagiciis miser et in facultatibus pauper,

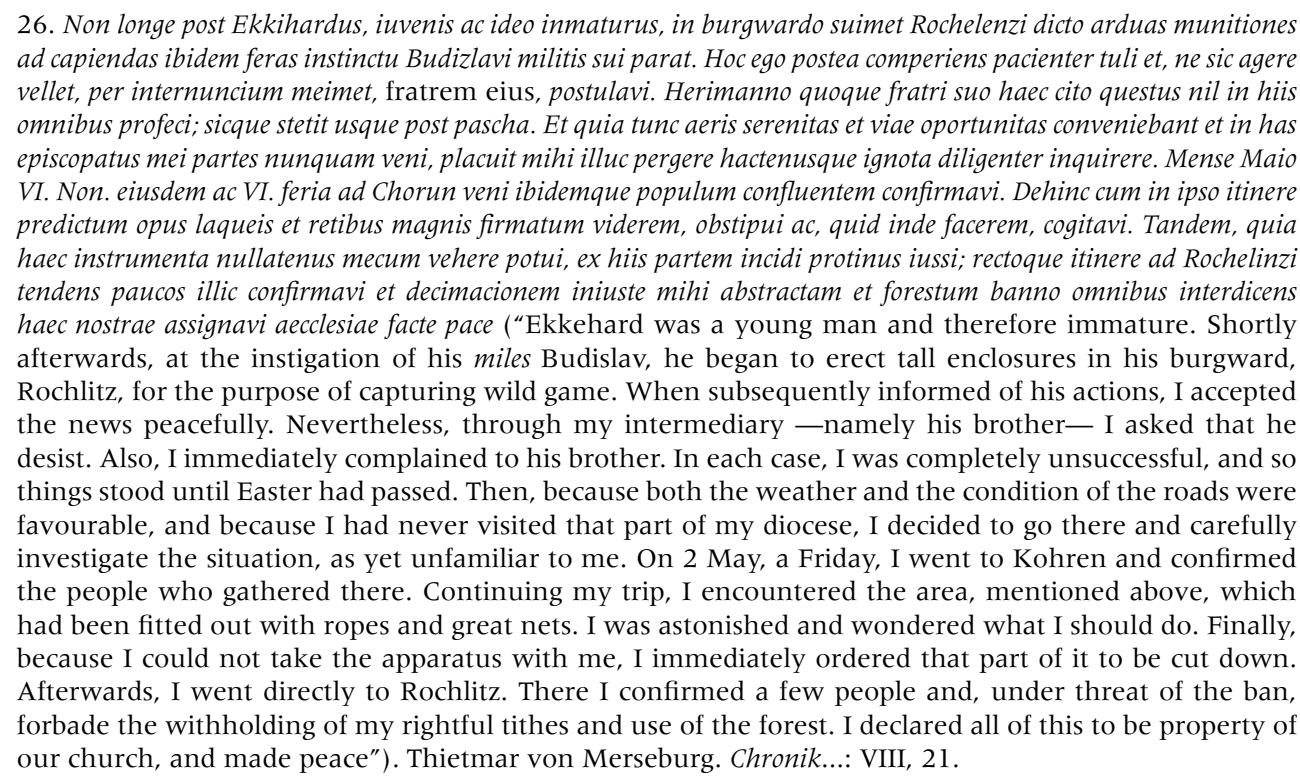

27. Tunc redii ad curtem supramemoratam; ibidemque VII dies cum manerem, audivi, quod milites Ekkihardi meis minarentur sociis. Ibi tunc cancellarius pernoctavit mecum et a me haec comperiens bene respondit. Postea congregationes multae mihi ad nocendum a predictis satellitibus factae a nostris custodibus ad tempus bonum preoccupatae sunt. Interim nuncium meimet ad imperatorem Magontiam misi pacemque eius supplex pecii. Quam cum Ekkihardus ex sua parte promitteret et frater suus diu a me desideratus a Polenia veniens dextera manu sua pacifica promitteret, uterque hanc non bene servavit. Namque homines VI flagellati ac depilati cum edificiis turpiter mutilatis approbant, qualiter tanti seniores ab aliis precaveri debeant. Satellites eorum more solito in me non / modo exarsere, verum etiam aliis melioribus nocuere. Archiepiscopum etenim Geronem in Wirbini et Sifridum comitem in Nicici pecierunt et, in quantum eis placuit, abstulerunt. ("Then I returned to my estate at Kohren where, after seven days, I heard that Ekkehard's milites were threatening my people. At that time, the chancellor happened to be spending the night with me. When I explained the situation to him, he responded favourably. On numerous occasions, those same warriors gathered together and tried to attack me, but our guards stopped them, in timely fashion. Meanwhile, I sent my representative to the emperor, at Mainz, and humbly sought his mediation. Now, on his own behalf, Ekkehard agreed to a truce; and his brother, whom I had long awaited, returned from Poland and offered his own hand in peace. Neither kept his word very well, however. Six flogged and shaved men, and as many devastated houses, prove how others must defend themselves against such lords. In their accustomed manner, their dependants not only raged against me, but also harmed other, better men. They attacked Archbishop Gero in Werben and Count Siegfried at Nischwitz, and took whatever they wished"). Thietmar von Merseburg. Chronik...: VIII, 22. 
quamvis in utroque eiusdem ordinis viros precellam cunctos, tamen contumeliam superius memoratam non solus pacior sine illis. ${ }^{28}$

Thietmar goes on to recount a number of unfortunate events that took place in dioceses throughout the region and kingdom. ${ }^{29}$ Merseburg apparently suffered a series of disquieting occurrences — seven serves died after eating poisonous mushrooms, a star remained visible for fourteen days and nights, and three wolves did great damage to the population: the people of Turingia were terrified, while unspeakable tribulations descended upon them and spread throughout the world in accordance with the divine will. ${ }^{30}$

\title{
4. In closing
}

Citing the dream when reflecting on Thietmar's consciousness of being both sinner and unworthy bishop, the historian Hans-Werner Goetz considers that

\begin{abstract}
Erneutzeigt sich in diesen Worten nicht nur die Realität von Träumen für den mittelalterlichen Menschen, sondern auch Thietmars Vorstellung. Seine Sünden kann er teuflischen Mächten anlasten, aber er bleibt doch dafür verantwortlich... Bei aller Toposhaftigkeit solcher Äußerungen führen diese doch zum Kern christlicher Anschauungen: Thietmar befürchtet die Gefährdung seines Seelenheils. ${ }^{31}$
\end{abstract}

This preoccupation showed by the chronicler about his wrongdoing is comprehensible within the framework of the chronicler's Christian cultural environment:

Seine Individualität aber fügt sich ein in ein christlich-mittelalterliches Verständnis seiner selbst; seine Identität ist in erster Linie selbstverständlich eine spezifisch mittelalterliche, religiöse Identität, seine Probleme sind religiöse Probleme... Thietmars Selbstzweifel haben viele Ursachen, aber sie entspringen der Angst (oder gar dem Bewusstsein?), versagt und damit das Seelenheil verwirkt zu haben: als Bischof, als Adliger, als Mensch und vielleicht sogar als Chronist. ${ }^{32}$

\footnotetext{
28. "In regard to my misdeeds, I am a wretch. In terms of my abilities, I am a pauper. In either case, however, I am far worse than all men of my order. Nevertheless, I have not been the only one to suffer the outrages noted above". Thietmar von Merseburg. Chronik...: VIII, 24.

29. Thietmar von Merseburg. Chronik...: VIII, 24-28.

30. Thietmar von Merseburg. Chronik...: VIII, 29-30.

31. "He shows again himself that there are not only the reality of dreams for the medieval people in these words but also Thietmar presentation. His sins, he blamed diabolical powers, but he remains responsible... in all the significance of such utterances perform this but the core of Christian beliefs: Thietmar fears the danger of his soul salvation". Goetz, Hans-Werner. "Die Chronik Thietmars...": 268.

32. "Nevertheless his individuality fits into a medieval Christian understanding of himself; his identity is primarily a matter of course, a specifically medieval, religious identity, his problems are religious problems ... Thietmar self-doubt have many causes, but they derive from the fear (or even the awareness?), fails
} 
Clearly the Merseburg chronicler considers the dispute among his many misdeeds (as anticipated abstractly in the dream) that had severely prejudiced the well-being of his bishopric: in fact, cutting the cords of the enclosures culminated the series of events unleashing the most violent reaction. However, the dialogue engaged in between this dream and the next sequence of events narrated by the chronicler should not be overlooked. It is at this point that the tale of the trials and tribulation suffered by the diocese he led, Merseburg, and the empire as well begins. Prominent among events particularly alarming to the bishop is the dispute involving the forest ceded by Otto II.

Viewed in this light, above and beyond the autobiographical references emphasising the bishop's self-criticism, consciousness of being a sinner unworthy of his position, and concern for the salvation of his soul, I am proposing a possible complementary interpretation for the inclusion of this dream in the Chronicle.

The narrative unfolds in the context of a series of disputes inherited by the diocese and its title holders, which include Thietmar, together with the Ekkehardiner, ${ }^{33}$ resulting from the suppression and subsequent reestablishment of the bishopric. The dream and the hostile acts Thietmar himself links to them allow him to specify and substantiate his prerogatives and duties as bishop: the power to ban; the obligation to visit the jurisdiction and to defend the collecting of taxes (tithes) and the bishopric's possessions against the attacks and abuses of laymen (and other ecclesiastics as well). ${ }^{34}$

Thus, in addition to expressing concern about the future of his Christian soul and explaining his sinful behaviour as a consequence of the drinking of a mixture of herbs, ${ }^{35}$ within the context of a diocese restored and in the process of fully reaffirming its prerogatives, narrating the dream presents the chronicler with a unique opportunity not only to repeat and confirm the criticism of the figure held responsible for its dissolution, archbishop Giselher, but also to reinforce the image of himself as an administrator - not always successful - dedicated to strengthening the episcopal see and guaranteeing the full exercise of all its rights, including ancient ones suspended at the time. ${ }^{36}$ By recounting his dream and seeking to explain it by means of events that had actually occurred, Thietmar, an explicit proponent of the Amtsbischöfe, makes use of it to revalidate his role and functions in the history he writes of a diocese convulsed by conflict.

and thus forfeited the salvation to have: as a bishop as a nobleman, as a human being and perhaps even as a chronicler". Goetz, Hans-Werner. "Die Chronik Thietmars...": 269.

33. Trillmich, Werner. "Einleitung...": XXII.

34. Thietmar von Merseburg. Chronik...: VIII, 21.

35. Thietmars Selbstbezichtigungen resultieren tatsächlich aus der Angst um das eigene Seelenheil ("Thietmar's self-accusations are indeed the results of his fear concerning his own salvation"). Goetz, Hans-Werner. "Die Chronik Thietmars...": 268-269.

36. Again, I am taking into consideration Thietmar's self-awareness of his role as bishop as complementary to his Christian recognition of himself as sinner, while Goetz concentrates on Thietmar's identity problems (particularly his sinful behaviour): Thietmar schrieb seine Chronik zur Selbstrechtfertigung: seines Bistums und seiner Politik, aber auch seiner selbst, als Buße und als Aufforderung an die Leser zur Gebetshilfe ("Thietmar wrote his chronicle for the justification of his bishopric and his politics, but also of himself, as penitence and as a call to the readers to aid in prayer"). Goetz, Hans-Werner. "Die Chronik Thietmars...": 269. 